Ruth Dassonneville

André Blais

Yves Dejaeghere

\title{
Staying with the Party, Switching or Exiting? \\ A Comparative Analysis of Determinants of Party Switching and Abstaining
}

Journal of Elections Public Opinion and Parties, accepted

\begin{abstract}
A large body of literature has investigated the factors that lead to abstention on the one hand or vote volatility on the other hand. We argue in this paper that the most fruitful approach is to simultaneously consider the exit, voice, and loyalty options. The analyses are based on data from the CSES and cover a broad set of advanced democracies. We demonstrate that while party switchers and abstainers have a lot in common, switching parties can be considered a more positive choice. Most importantly, contrary to what previous research suggested and in contrast to abstainers, party switchers cannot be characterized as frustrated with politics. Furthermore, the supply side does to a certain extent affect whether voters choose to remain loyal, switch parties, or abstain from voting.
\end{abstract}

\section{Keywords}

Electoral volatility; abstention; political participation; voting behavior; dissatisfaction 


\section{Introduction}

In his classic book Exit, Voice, and Loyalty, Hirschmann (1970) has powerfully argued that having loyal supporters is fundamental for political parties. And mass parties (Duverger, 1954) seemed to accomplish this goal. The ' $60 \mathrm{~s}$ and ' $70 \mathrm{~s}$ of the previous century can be considered dominated by loyalty to political parties (Lipset and Rokkan, 1967)

From the late seventies onwards, however, a gradual erosion of stability in voting behavior has been pointed out (Pedersen, 1979). Furthermore, turnout levels have been shown to be decreasing over the past few decades (Franklin, 2004; Gray \& Caul, 2000). With loyalty towards a particular party decreasing, it seems that voters are making use of voice (party switching) and exit (abstaining) options more often.

The Hirschmann framework leads us to expect that it is dissatisfaction that is causing voters to refrain from loyally voting for their party in subsequent elections. We know, however, that it is crucial to distinguish between political dissatisfaction towards one particular party and a more generalized sense of political dissatisfaction (Bélanger, 2004; Miller \& Listhaug, 1990). In a first step, therefore, we investigate how different types of political dissatisfaction are related to exit, voice and loyalty options in voting behaviour.

A number of scholars have already implemented Hirschmann's theory in the field of voting behaviour (Bélanger, 2004; Hooghe, Marien \& Pauwels, 2010; Kang, 2004; Kselman \& Niou, 2010; Weber, 2011). These studies, however, either focus on one or a limited number of countries, or do not aim to investigate how the context affects whether voters choose exit, voice or loyalty. In a second step, we therefore assess how the number of options (i.e., parties) voters have affects the extent to which they choose an exit or voice option.

This paper addresses the question of how dissatisfaction translates either in party switching or abstention and how contextual differences affect the choice between the two options. We study volatility and abstention at an individual level in a broad sample of advanced industrialized countries. We do so by making use of data from the second and third modules of the Comparative Study of Electoral Systems (CSES). We investigate dynamics in voting behaviour among 34,568 individuals in 36 elections and 22 countries. ${ }^{i}$ We start with an overview of the literature on volatility and turnout and elaborate on our expectations. The next section describes the data and methods, after which we present the results. We end with concluding remarks on the implications of our findings and caveats of the current analyses. 


\section{Voice or Exit?}

A number of scholars have pointed out that we are witnessing a 'political malaise' in advanced industrial democracies, with levels of satisfaction and trust in politics decreasing (Bélanger, 2004; Hetherington, 1998; Norris, 1999). While a fairly general trend, the work of Hirschmann (1970) leads us to expect that this 'malaise' is linked to different behavioural consequences. Indeed, Hirschmann has argued that people have different ways of dealing with dissatisfaction. Customers dissatisfied with a particular product or brand, for example, can continue buying that product (loyalty), voice their dissatisfaction by complaining to the producer (voice), or decide not to buy that product anymore and choose another product instead (exit).

Hirschmann's theoretical framework has previously been applied in the field of political science (Bélanger, 2004; Kang, 2004; Kweit, 1986; Weber, 2011). Most of these authors have focused on how dissatisfaction can lead voters to leave the party they earlier voted for or were a member of, which has been framed as Hirschmann's exit option. Not focusing on particular parties but on the party system more generally, we have a slightly different take on how exit, voice and loyalty are options for voters. We argue that when a voter is politically dissatisfied, as a first option this voter can decide to remain loyal to her previous party and vote for this party in subsequent elections. A second option is to voice dissatisfaction by deserting the earlier preferred party and voting for another party instead. This signaling of dissatisfaction by changing parties is much alike the pattern of third party voting referred to by Bélanger (2004). While switching implies that a certain party is deserted, this voter still turns out to vote and hence does not leave the party system. For this reason, we refer to this second possibility as the voice-option. Finally, a dissatisfied voter can think none of the other parties are worthy of her vote and decide to abstain. We label this third option as the exit-option, as the voter leaves the party system (Hooghe, Marien, Pauwels, 2011).

Scholars initially disagreed on the presence of increasing volatility (Mair, 1993). As empirical evidence on the growth of volatility has accumulated, however, this has by now been considered an established fact (Dalton et al., 2000; Mair, 2008). For declining turnout levels as well, the empirical evidence is convincing and accumulating (Blais, 2010; Franklin, 2004; Gray $\&$ Caul, 2000). 
Both increasing volatility and decreasing turnout are caused by the wider process of dealignment. Additionally, party switching and abstention are closely linked in the sense that each of them contributes to electoral instability. Therefore, we side with Zelle, who stated: '.. even though nonvoting is a vital aspect of electoral change just as party switching is, (...) it is equally as vital to investigate each of these aspects in its own right' (Zelle, 1995: 320).

\section{Explaining Switching and Abstaining}

\subsection{Individual-level Determinants: Political Satisfaction}

Whether or not citizens turn out to vote has repeatedly been shown to be affected by their political attitudes. Voters have been argued to be more dutiful compared to nonvoters (Blais, 2000; Riker \& Ordeshook, 1968) and they have been found to have higher levels of political efficacy (Karp \& Banducci, 2008), political trust and satisfaction with democracy (Grönlund \& Setälä, 2007; Hetherington, 1999). Interestingly, vote switching as well has been linked to scoring low on these fundamental political attitudes. Zelle (1995) formulated the hypothesis of party switching as such being caused by 'frustration'. The mechanism suggested to cause vote switching by Zelle is one in which a voter is first disappointed with her party. This frustration with a particular party is then thought to trigger a sense of disaffection with the entire political system and all parties. As a way to voice this frustration, a floating voter switches parties.

Investigating his floating voter hypothesis, Zelle (1995) finds that floating voters in Germany have a lower level of trust in parties compared to stable voters. Additionally, they like their preferred party less than stable voters do and they are less satisfied with the political system. As such, Zelle (1995) provides evidence that floating voters have political attitudes very much alike those of nonvoters and others have confirmed this image (Dalton \& Weldon, 2005; Dassonneville, 2012; Söderlund, 2008).

The 'frustrated floating voter' hypothesis implies that, like citizens abstaining from voting, volatile voters are politically dissatisfied. Political satisfaction is a broad concept, however, and encompasses both specific and more general attitudes towards the regime or the political system at large. Like political support, therefore, political satisfaction can be thought of

as a continuum ranging from diffuse to specific (Linde \& Ekman, 2003; Norris, 1999). These dimensions of satisfaction are reflected in the work of Söderlund (2008), who investigates the impact of satisfaction with a particular party on volatility and abstention while explicitly 
controlling for more general attitudes of satisfaction with democracy or efficacy. As Söderlund (2008: 222) states: 'those people who are critical of certain parties at certain brief periods of time need not be critical of the political system as a whole, and vice versa'. While in essence different, it is clear though that dissatisfaction with a particular party can 'spill over to influence judgments of the regime as a whole’ (Miller \& Listhaug, 1990: 357).

Zelle (1995) stressed the similarities between nonvoters and voters switching parties and argued that switching parties is triggered by a general feeling of political dissatisfaction. Only focusing on volatile voters and standpatters, however, he could not assess the difference in levels of satisfaction between volatile voters and abstainers. Furthermore, Zelle (1995) did not distinguish between specific and diffuse feelings of political satisfaction. The fact that scholars describe different degrees of dissatisfaction, from diffuse to specific, leads us to expect these differences to be reflected in voters' electoral behaviour as well. Voters switching parties should not necessarily be dissatisfied with the political system as such, while voters abstaining are more likely to be so.

Regarding satisfaction with a specific party, Söderlund (2008) demonstrated that in the Nordic countries both voters switching parties and voters abstaining are dissatisfied with the performance of the party they previously voted for. By switching parties the dissatisfied can send a strong signal to their previously preferred party, by not only punishing that party but also strengthening its competitors (Kselman and Niou, 2010). Clearly, there are theoretical as well as empirical reasons for expecting dissatisfaction with one's previous party to increase the probability not only of abstaining but of switching as well. Additionally, in an analysis of third party voting, Bélanger (2004) has shown that the effect of dissatisfaction with a specific party on switching to a third party is stronger than the effect on abstention. Not limiting the analyses to third parties only, but focusing on switching parties in general and for a broader set of countries, we expect to find dissatisfaction with a specific party to explain both party switching and abstention. The effect on party switching is furthermore expected to be stronger than the effect on abstaining from voting.

Hypothesis 1: Dissatisfaction with the party previously voted for increases the probability of abstaining and of the probability of party switching even more. 
A sense of dissatisfaction with a particular party can eventually develop into dissatisfaction with all parties and the political system at large (Gidengil et al., 2001; Miller \& Listhaug, 1990) and it is this more general sense of political dissatisfaction that should lead voters to abstain from voting. In line with the frustrated floating voter hypothesis, furthermore, voters switching parties are also expected to have a lower level of general political satisfaction compared to stable voters. In line with what Bélanger (2004) has shown for voting for third parties on the one hand and abstention on the other, we expect this difference to be more pronounced when contrasting abstainers with stable voters.

Hypothesis 2: Political dissatisfaction increases the probability of switching parties and increases the probability of abstaining even more.

\subsection{The Party System: Number of Parties}

Individual-level characteristics can be considered crucial determinants of stability, switching and abstaining. If we want to fully understand why voters choose one particular option, however, we have to acknowledge the fact that vote choices are not made in a void (Anderson \& Dalton, 2010). For this reason, we have to take into account characteristics of the party system as well. We focus on the number of parties in a system, as a way to take the supply side into account.

The number of parties should self-evidently affect the probability that a voter switches parties from one election to another. The logic is straightforward; more parties increase the probability of switching because there are simply more options to choose from. Furthermore, with more parties available, the likelihood increases that a voter finds an alternative to her previous choice that is worthy of her vote (Blais \& Gschwend, 2010). So far, this link between the number of options available and vote switching has been investigated at an aggregate level. Most of the available aggregate-level evidence does suggest that the number of parties in a system significantly increases net volatility (Bartolini \& Mair, 1990; Mainwaring \& Zoco, 2007; Lane \& Ersson, 2007). Obviously, there could also be reciprocal effects of unstable electorates leading to party fragmentation. Tavits (2008), however, has convincingly shown that in young democracies volatility follows from changes in the party system, not vice versa. At an individuallevel as well, we expect that more parties increase the probability of vote switching from one election to another. 
Hypothesis 3: A higher number of parties increases the probability of switching parties.

The link between the number of parties and turnout has received wide scholarly attention. Nevertheless, conflicting findings have led to different expectations on how the number of parties affects individual voters' likelihood of turning out to vote. On the one hand, it is claimed that with more options available, the probability that a voter finds a party upon her liking increases. Additionally, more parties also imply that more actors are trying to get citizens out to vote. Consequently, more parties are expected to lead to higher levels of turnout (Banducci \& Karp, 2009; Blais \& Aarts, 2006). The opposite finding, more parties being associated with lower levels of turnout at an aggregate level, has been found and interpreted as well. With more parties running for election, the link between the outcome of the election and the formation of the (coalition) government is less direct. Consequently, voters perceive their vote as less decisive and are less likely to turn out (Jackman, 1987). Furthermore, the fact that with an increasing number of parties the complexity of the system increases might cause voters to abstain. This as well, could be a reason for lower turnout as the number of parties is higher (Blais \& Dobrzynska, 1998). In an effort to integrate both theories, Taagepera, Selb and Grofman (2014) have recently suggested a logical model and show that we should expect a curvilinear relation. Their findings indicate that turnout increases first but decreases afterwards as the number of parties increases. In further efforts to disentangle what individual causal mechanisms are at play, scholars have only recently started to investigate the effect of the party system on turnout by means of comparative individual-level data. These efforts have indicated that there is evidence for both processes, and depending on what factors are controlled for the estimated effect of the number of parties on individual-level turnout can change direction (Banducci \& Karp, 2009; Brockington, 2004; Kittilson \& Anderson, 2010). We hypothesize that the presence of more parties decreases the likelihood that voters will abstain from voting.

Hypothesis 4: A higher number of parties decreases the probability of abstaining.

\subsection{Combining Individual-level and Party System Determinants}


Empirical research on the effect of institutional factors on volatility and turnout is mostly at an aggregate level. Research on the individual-level determinants of both party switching and abstention on the other hand, mostly makes use of survey data within one or a few countries. As there are important factors at both the individual and the contextual level, 'an ideal analysis would consider both types of factors simultaneously' (Powell, 1986: 23). The CSES dataset not only allow us to integrate individual and contextual-level determinants, but also to investigate how contextual factors mitigate individual-level effects.

Previous research on how exit, voice and loyalty are options to express dissatisfaction have focused on one or a limited number of countries (Bélanger, 2004; Bélanger and Nadeau, 2005; Kang, 2004; Hooghe, Marien and Pauwels, 2010) or do not aim to explain country-level differences with respect to the individual-level mechanisms (Weber, 2011). In the current paper, we build on this individual-level research and investigate how the context can mitigate the effect of dissatisfaction.

We can expect the number of alternatives voters have to affect what option voters choose to voice their dissatisfaction. Not only do we expect dissatisfaction to lead to switching, we furthermore assume that having a higher number of alternatives on Election Day strengthens the link between dissatisfaction with one's party and the propensity to switch parties. The underlying logic is that when a voter has few alternatives to choose between, she has less viable or ideologically close options to switch to. Consequently, with fewer options the dissatisfied might be more inclined to remain loyal to their previous party. Consequently, with more parties at offer a voter should be swayed more easily to voice dissatisfaction with her party by switching to another party - either a major or traditional party or a protest party. If so, dissatisfaction might translate less easily into abstention when the number of parties is higher.

Hypothesis 5: As the number of parties increases, the relation between dissatisfaction with the party previously voted for and the probability of switching gets stronger

\section{Data and Method}

\subsection{Data}

We make use of data from the second and third modules of the CSES-project. The project provides data from surveys that use identical question wording and coding of items and that were 
all in the field shortly after national elections. As a result, the CSES project enhances the validity of cross-national research on voting behaviour (Nevitte et al., 2009).

We focus on voters' likelihood of choosing the exit, voice or loyalty options vis-à-vis the party they supported in the previous election. Therefore, we constructed a dependent variable that has three possible outcomes: (1) loyally voting for the same party in two consecutive elections, (2) switching parties, (3) switching from voting in the first election to abstaining in the second. Since the CSES-data are cross-sectional, we use the recall question about previous voting behaviour as the reference point for the analysis. Only those respondents who indicated that they voted in the previous election and who revealed their vote choice are included in the analysis. Quite logically, our interest in the impact of satisfaction with the party previously voted for on party switching and abstaining implies a focus on those respondents who did vote in the previous election.

A question on recalled voting behaviour in the previous election was included from the second CSES-module onwards. Because the question is not asked in all the CSES-surveys, our dataset is restrained to those countries for which surveys did include a recall question. Additionally, we focus on voting in parliamentary elections, excluding presidential elections. An extra condition for elections to be included in the dataset was that they were conducted freely according to the standards of Freedom House. ${ }^{\text {ii }}$ Recall questions on previous voting behaviour are imperfect measures, most importantly because they lead to a bias towards consistency (Converse, 1962; Festinger, 1957). Memory problems further add to an overestimation of stable vote choices and civic duty additionally leads respondents who abstained to report that they did go out to vote (Waldahl \& Aardal, 2000). Acknowledging that recall questions come with measurement bias, we cross-validated the data by comparing respondents' recalled voting behaviour with actual election results. Only the election samples for which the recalled vote closely matched election results were retained. ${ }^{\text {iii }}$ This step reduces the sample of countries included to mostly established democracies, limiting the generalizability of our results. We prefer, however, to be cautious in our use of recalled voting behaviour for assessing the causes of electoral volatility.

Changes in the party system between two consecutive elections complicate the task of defining what changes in vote choices are to be defined as party switches. Voters who indicated having voted for a party that split from the party they previously voted for are treated as stable. 
Likewise, voters who previously voted for one of the parties of a merger of parties and voted for this merged party are treated as stable voters. ${ }^{\text {iv }}$

Missing data on some of the independent variables further reduced the dataset to 34,568 individuals in 36 elections in 22 countries. The elections included in the analysis are listed in Appendix 1, with the distribution of loyalists, switchers, and exiters. As expected, abstainers are underrepresented in the surveys (about 5\% of the sample). Abstainers are somewhat more numerous and add up to over $10 \%$ of the sample in the Norwegian 2002, the British 2005 and the Irish 2007 election and to over 30\% of the sample in the Polish 2005 election. Switchers typically constitute about a quarter of the sample but form an absolute majority in the Irish 2007 election. Furthermore, switchers are particularly numerous in the Dutch 2002 and 2010 elections. As for loyalists, they are usually about two-thirds of the cases, with the maximum being observed in the 2009 election in Uruguay.

\subsection{Measures}

As a measure of respondents' general level of political satisfaction we include an item on satisfaction with the democratic process. The question wording is 'On the whole, are you very satisfied, fairly satisfied, not very satisfied or not at all satisfied with the way democracy works in [country]?' This 1 to 4 item of satisfaction with democracy (reverse coding) is included in the analyses and was standardized to run from 0 to 1 . The use of this item has previously been criticized (Canache, Mondak \& Selegson, 2001; Linde \& Ekman, 2003). The lack of an alternative measure of political support such as political trust in the CSES-dataset leads us to rely on the satisfaction with democracy item, which Anderson (2001: 10) has called "a reasonable (albeit imperfect) indicator that we can use to test our theories".

In order to investigate voters' level of satisfaction with the party they previously voted for, we use a measure of affect. Doing so, we remain close to Zelle's original conception of satisfaction. The measure is the like-dislike rating (on a scale from 0 to 10) of the party the respondent indicates having voted for in the previous election. For reasons of comparability, the item on satisfaction with one's party was standardized to run from 0 to 1 .

As partisans are less likely to switch parties or to abstain from voting, we control for the effect of party identification. Therefore, we make use of the CSES-question asking whether they feel close to a particular party (yes $=1$ or no=0). Controlling for partisanship should help to 
neutralize the impact of long-term predispositions on the short-term party evaluations we are interested in.

Converse already pointed out in 1962 that "The same theory which predicts that the less involved are more susceptible to party change suggest that the less involved will also give less accurate accounts of past political behavior" (Converse, 1962: 580). Given that there is no other option for investigating party switching than to rely on information from recall questions, it could be claimed that we should control for the effect of factors such as levels of education or political knowledge. Therefore we also verified whether our conclusions hold when controlling for voters' level of education (whether or not they have a college degree), political knowledge (based on the three knowledge questions included in the CSES modules), and age and gender.

At a contextual level, we are interested in how the number of parties affects the probability of stability, switching and abstaining respectively. Therefore, we rely on the index of the effective number of parties suggested by Laakso and Taagepera (1979). By using this measure instead of the mere number of parties on the ballot, we capture the number of viable alternatives voters have on Election Day. The data come from Gallagher (2014). Additionally, we control for whether or not voting was compulsory, as this obviously strongly affects the probability that a voter abstains from voting (Powell, 1986). Therefore, we include a dummy variable for whether or not voting was compulsory, with strict sanctions; see IDEA (Lopez Pintor \& Gratschew, 2002). Given our focus on the number of parties in a system, we present a parsimonious model with these contextual variables only. In order to ascertain that it is the number of parties and therefore the size of the choice set that matters, we verify whether the results hold when controlling for other contextual-level variables. Because the number of parties is clearly related to the electoral system (Neto \& Cox, 1997), we control for disproportionality (using the least squares indicator). Furthermore, recent studies have stressed the importance of polarization rather than formal electoral rules as a factor affecting citizens' political attitudes and behaviour (Dalton, 2008; Kittilson \& Anderson, 2010; Thomassen, 2014). Therefore, we assess whether our results with regard to the number of parties hold when controlling for the level of polarization in a party system.

\subsection{Method}


The data have a hierarchical structure, with respondents nested in elections and these elections nested in countries. Additionally, the aggregate-level descriptive statistics of our dependent variable presented in Appendix 1 indicate that there is a substantial amount of variation at the level of elections to be taken into account. Furthermore, given that we are interested in explanatory factors at the individual as well as the contextual level, we make use of multilevel modeling (Steenbergen \& Jones, 2002). We specify random intercepts across the electionsamples and for testing the interactive effect of contextual and individual-level variables, we additionally specify a random slope for the like-dislike variable.

The categorical nature of our dependent variable, with three possible outcomes, necessitates the use of multinomial regression models. Therefore, we present the results of a series of multinomial multilevel regression models. The models are run via the runmlwin command in Stata (Lecki \& Charlton, 2013), which allows for estimating complex multilevel models. Starting values for estimations are obtained through a second order penalized quasilikelihood (PQL2) estimation, after which final models are fitted using Markov Chain Monte Carlo (MCMC) methods. We do so because quasi-likelihood methods for multilevel modeling with discrete responses have been shown to give biased results (Lecki \& Charlton, 2013). The fit of models estimated by MCMC approximation can be assessed by looking at the Bayesian Deviance Information Criterion (DIC), with a lower value indicating a better model-fit (Spiegelhalter et al., 2002).

\section{Results}

The results of the analyses are presented in Table 1. As a first step, we estimated an interceptonly model, which gives insights on the total amount of variance at the level of elections. While the estimates of this intercept-only model are not shown, it is important to note that there is more contextual-level variation in the extent to which voters abstain from voting $\left(\sigma^{2}=1.822\right)$ than there is for party switching $\left(\sigma^{2}=0.386\right)$.

Performing a multinomial logistic regression on a dependent variable with three outcome categories gives us two sets of estimates, each of them assessing the impact of the variables for an outcome relative to the base category (which is voting loyally for the same party in two consecutive elections). Additionally, we present the effect of the independent variables on the probability of abstaining contrasted with switching parties. This set of parameters is nothing more 
than a linear transformation of the original parameters (Gidengil et al., 2001; Whitten \& Palmer, 1996).

We first look at the effect of the extent to which respondents like the party they previously voted for. In line with our first hypothesis, we expect higher levels of satisfaction to decrease the probability of abstaining and to decrease the probability of switching even more strongly. As clear from the results in Table 1, the more a voter likes the party she previously voted for, the smaller her probability of both switching and of abstaining. Furthermore, the extent to which a voter likes her previous party decreases the probability of switching more strongly than the probability of abstaining, as we hypothesized. The more a voter likes her previous party, the more likely she is to abstain rather than to switch to another party. Because log-odds coefficients of a multinomial regression model are hard to interpret, in Figure 1 we graphically present the estimated effect of the extent to which a voter likes her previous party on the probability of being loyal, switching parties and abstaining respectively. Figure 1 clarifies that satisfaction with one's previous party mostly affects two behavioural options; the more one likes the party previously voted for, the higher the probability of being loyal to that party and the smaller the probability that a voter switches parties. At the same time, whether or not voters abstain from voting is hardly affected by the extent to which they like the party they previously voted for.

\section{[FIGURE 1 ABOUT HERE]}

Our second hypothesis is that a general sense of political satisfaction reduces the probability that a voter abstains from voting. Additionally, it was stated that higher levels of political satisfaction would reduce the likelihood of party switching, but to a lesser extent than for abstention. As can be read from the results in Table 1, this is not what our results point at. A higher level of satisfaction with democracy does significantly decrease the probability of abstaining compared to remaining loyal to the party previously voted for, but it does not significantly affect the probability of switching parties.

The fact that we standardized the main independent variables to both run from 0 to 1 allows us to directly compare their effect on switching and abstaining. Coefficients are bigger for satisfaction with one's previous party, indicating that for understanding both why voters switch 
parties and why they decide to abstain, it is more important to look at how voters think about their party than to look at more general feelings of political dissatisfaction.

(A lack of) satisfaction is linked to the extent to which voters switch parties or abstain from voting, but we know that vote choices are not made in a void. Reflecting on the way in which the context matters, we hypothesized that a higher number of parties would increase the probability of switching parties (H3), but decrease the probability of abstaining (H4). Our results do indicate that a higher number of parties significantly increases the probability that a voter switches compared to the probability that she remains loyal to her party. In contrast to our fourth hypothesis, however, the probability of abstaining compared to remaining loyal is not significantly affected by the number of parties. Clearly, the number of viable options available to voters affects whether they will switch parties or remain loyal. The probability of abstaining, by contrast, is not significantly smaller when voters have more options to choose between. While not confirming our fourth hypothesis, this non-finding can hardly be considered surprising; previous studies do not agree on the effect of the number of parties on turnout. Finally, compulsory voting evidently reduces the probability that a voter abstains.

\section{[TABLE 1 ABOUT HERE]}

Besides hypothesizing about a main effect of the number of parties at offer, we also hypothesized a higher number of parties to strengthen the relation between voters' assessment of their previous party and their probabilities of switching (H5). In Table 2, we verify this by including a cross-level interaction between the effective number of parties and voters' like-dislike rating of their previous party. Self-evidently, random slope variances for the like-dislike variable are specified in this model, both for the contrast between switching and loyalty $\left(\sigma_{\text {like dislike election }}^{2}\right.$ switching $)$ and for the contrast between abstention and loyalty $\left(\sigma^{2}\right.$ like dislike election abstaining $)$. The data confirm the fifth hypothesis. The more a voter likes her previous party, the lower the probability of switching. As the number of parties increases, this negative effect is strengthened (as clear from the negative and significant interaction term). Additionally, and surprisingly, the negative effect of satisfaction on abstaining is strengthened as the number of parties in a system increases.

\section{[TABLE 2 ABOUT HERE]}


The presence of more parties renders party switching a more viable option. Substantively, as the number of parties - and therefore the options available - increases, dissatisfaction with one's party translates more easily into party switching. We graphically present this interaction effect in Figure 2. The graph illustrates the negative relation between the extent to which one likes one's previous party and the probability to switch parties for party systems of varying size. In both small and large party systems, liking one's previous party decreases the probability that a voter switches parties. In large party systems, however, the impact is bigger. With an ENEP of 7 , the probability of switching decreases from $91 \%$ for a minimum level of satisfaction (0) to $9 \%$ only if a voter gives the maximum rating to her previous party (1). For small party systems $(\mathrm{ENEP}=3)$, by contrast, the probability of switching decreases from $72 \%$ to $9 \%$ as a voter moves from the lowest to the highest rating.

\section{[FIGURE 2 ABOUT HERE]}

The results of the models with all control variables are presented in Appendix $5^{\mathrm{v}}$ and indicate that our findings are robust to controlling for some crucial individual-level predictors as well as other contextual-level factors.

\section{Discussion and Conclusion}

Both switching parties and abstaining from voting can be considered close alternatives and their effects add up to volatility in election results. Despite the theoretical and empirical link, however, switching parties and abstaining have so far not been investigated simultaneously for a broad set of democracies.

Doing so leads to a number of unexpected findings, elucidating important differences in the profiles of voters choosing these two options. Our multivariate analyses, in which we not only look at party switching versus stability but also at the contrast with abstaining from voting, provide important insights into Zelle's frustrated floating voter hypothesis. Voters who switch parties are not dissatisfied with politics in general but party switchers clearly are dissatisfied with the party they previously voted for. This sense of dissatisfaction that is directed at a specific party does not, however, strongly affect the probability that a voter decides to abstain from voting. A 
general sense of political dissatisfaction, on the other hand, does increase the probability that a voter abstains from voting, but party switchers are not more dissatisfied in general. In contrast to what Zelle (1995) observed, we do not come to the conclusion that volatile voters are 'frustrated about politics'. Our results indicate that those who switch parties are not frustrated about politics; they are dissatisfied with a particular political party but still rely on the political system to voice their dissatisfaction.

Dissatisfaction with a party increases the probabilities of both party switching and abstaining, but a general sense of political dissatisfaction affects the probability that voters will abstain from voting only. Whether voters are dissatisfied with a specific party or with politics in general therefore affects what option they will use to voice dissatisfaction. While abstainers turn away from politics, voters switching parties make a more positive choice to express their dissatisfaction with the party previously voted for. Volatile voters are not randomly floating out of frustration; rather, they use their ballot to hold parties accountable for past performance.

On the supply side, the number of parties is an important predictor of party switching; voters are more likely to switch parties from one election to another if there are more options to choose between. Additionally, a higher number of parties strengthens the link between dissatisfaction with one's party and the probability to switch to another party. How voters voice dissatisfaction with their party therefore depends to a considerable degree on how many options they have. If the choice set is large, voters are more likely to switch to another party when they are not satisfied with the party they previously voted for. In short, the presence of many parties renders party switching a more viable option for voters who are dissatisfied with the party they previously preferred.

Finally, it is important to keep in mind one important limitation of our study. Because we believe it is important to look at patterns of voting behaviour that can be generalized across political systems, we have used a large international dataset (CSES). In doing so, we had to rely on recall questions about voters' behaviour in the previous election. Ideally, of course, we would like to use panel data to avoid the pitfalls of recall questions. It would thus be useful to verify whether the patterns that have been uncovered here hold when panel data are utilized. Furthermore, investigating this question with panel data covering multiple waves could provide more insights in how satisfaction with a specific party can trigger a general sense of political 
dissatisfaction and whether disappointed party switchers eventually decide to abstain from voting.

\section{References}

Anderson, C. (2002) Good questions, dubious inferences, and bad solutions: Some further thoughts on satisfaction with democracy. Unpublished manuscript, Maxwell School of Citizenship and Public Affairs, Syracuse University.

Anderson, C.J., Dalton, R.J. (2010) Citizens, Context and Choice. How Context Shapes Citizens' Electoral Choices (Oxford: Oxford University Press).

Banducci, S. \& Karp, J. (2009) Electoral systems, efficacy, and voter turnout, in: H. Klingemann (ed) The Comparative Study of Electoral Systems (Oxford: Oxford University Press), pp. 109-134.

Bartolini, S. \& Mair, P. (1990) Identity, Competition and Electoral Availability. The Stability of European Electorates 1885-1985 (Cambridge: Cambridge University Press).

Bélanger, E. (2004) Antipartyism and third-party vote choice: A comparison of Canada, Britain, and Australia. Comparative Political Studies, 37(9), pp. 1054-1078.

Bélanger, E. \& Nadeau, R. (2005) Political trust and the vote in multiparty elections: The Canadian case. European Journal of Political Research, 44(1), pp. 121-146.

Blais, A. (2000) To Vote or Not to Vote? The Merits and Limits of Rational-Choice Theory (Pittsburgh: University of Pittsburgh Press).

Blais, A. (2010) Political participation, in: L. LeDuc, R.G. Niemi \& P. Norris (eds) Comparing Democracies 3: Elections and Voting in the 21st Century (London: Sage), pp. 165-183.

Blais, A. \& Aarts, K. (2006) Electoral systems and turnout. Acta Politica, 41(2), pp. 180-196.

Blais, A. \& Dobrzynska, A. (1998) Turnout in electoral democracies. European Journal of Political Research, 33(2), pp. 239-261.

Blais, A. \& Gschwend, T. (2010) Strategic defection across elections, parties and voters, in: R.J. Dalton \& C.J. Anderson (eds) Citizens, Context and Choice. How Context Shapes Citizens' Electoral Choice, (Oxford: Oxford University Press), pp 176-193.

Brockington, D. (2004) The paradox of proportional representation: The effect of party systems and coalitions on individuals' electoral participation. Political Studies, 52(3), pp. 469-490. 
Canache, D., Mondak, J. \& Seligson, M. (2001) Meaning and measurement in cross-national research on satisfaction with democracy. Public Opinion Quarterly, 65(4), pp. 506-528.

Converse, P.E. (1962) Information flow and the stability of partisan attitudes. The Public Opinion Quarterly, 26(4), pp. 578-599.

Dalton, R.J. (2008) The quantity and the quality of party systems. Party system polarization, its measurement, and its consequences. Comparative Political Studies, 41(7), pp. 899-920.

Dalton, R.J. \& Anderson, C.J. (eds) (2010) Citizens, Context and Choice. How Context Shapes Citizens' Electoral Choice (Oxford: Oxford University Press).

Dalton, R.J., McAllister, I. \& Wattenberg, M. (2000) The consequences of partisan dealignment, in: R.J. Dalton \& M. Wattenberg (eds) Parties without Partisans (Oxford: Oxford University Press), pp. 37-63.

Dalton, R.J. \& Weldon, S.A. (2005) Public images of political parties: A necessary evil? West European Politics, 28(5), pp. 931-951.

Dassonneville, R. (2012) Electoral volatility, political sophistication, trust and efficacy: A study on changes in voter preferences during the Belgian regional elections of 2009. Acta Politica, 47(1), pp. 18-41.

Duverger, M. (1954) Political Parties: Their Organization and Activities in the Modern State (London: Methuen).

Festinger, L. (1957) A Theory of Cognitive Dissonance (Stanford: Stanford University Press).

Franklin, M.N. (2004) Voter Turnout and the Dynamics of Electoral Competition in Established Democracies since 1945 (Cambridge: Cambridge University Press).

Gallagher, M. (2014) Electoral Systems Website, available at

<www.tcd.ie/Political_Science/staff/michael_gallagher/ElSystems/Docts/ElectionIndices.p df $>$ (accessed 16 April 2014).

Gidengil, E., Blais, A., Nevitte, N. \& Nadeau, R. (2001) The correlates and consequences of antipartyism in the 1997 Canadian election. Party Politics, 7(4), pp. 491-513.

Gray, M. \& Caul, M. (2000) Declining voter turnout in advanced industrial democracies, 1950 to 1997: The effects of declining group mobilization. Comparative Political Studies, 33(9), pp. 1091-1122.

Grönlund, K. \& Setälä, M. (2007) Political trust, satisfaction and voter turnout. Comparative European Politics, 5(4), pp. 400-422. 
Hetherington, M. (1998) The political relevance of political trust. American Political Science Review, 94(4), pp. 791-808.

Hetherington, M. (1999) The effect of political trust on the presidential vote, 1968-96. American Political Science Review, 93(2), pp. 311-326.

Hooghe, M., Marien, S. \& Pauwels, T. (2011) Where do distrusting voters turn if there is no viable exit or voice option? The impact of political trust on electoral behaviour in the Belgian regional elections of June 2009. Government and Opposition, 46(2), pp. 245-273.

Hirschman, A.O. (1970) Exit, Voice, and Loyalty (Cambridge: Harvard University Press).

Jackman, R.W. (1987) Political institutions and voter turnout in the industrial democracies. The American Political Science Review, 93(2), pp. 405-424.

Kang, W. (2004) Protest voting and abstention under plurality rule elections: An alternative public choice approach. Journal of Theoretical Politics, 16(1), pp. 79-102.

Karp, J.A. \& Banducci, S.A. (2008) Political efficacy and participation in twenty-seven democracies: How electoral systems shape political behaviour. British Journal of Political Science, 38(2), pp. 311-334.

Kittilson, M.C. \& Anderson, C.J. (2010) Electoral Supply and Voter Engagement, in: R.J. Dalton \& C.J. Anderson (eds) How Context Shapes Citizens' Electoral Choices (New York: Oxford University Press), pp. 33-54.

Kselman, D. \& Niou, E. (2010) Protest voting in plurality elections: A theory of voter signaling. Public Choice, 148(3/4), pp. 395-418.

Kweit, M.G. (1996) Ideological congruence of party switchers and nonswitchers: The case of party activists. American Journal of Political Science, 30(1), pp. 184-196.

Laakso, M. \& Taagepera, R. (1979) "Effective" number of parties: A measure with application to West Europe. Comparative Political Studies, 12(1), pp. 3-27.

Lane, J.-E. \& Ersson, S. (2007) Party system instability in Europe: Persistent differences in volatility between West and East. Democratization, 14(1), pp. 92-110.

Lecki, G. \& Charlton, C. (2013) Runmlwin: A program to run the MLwiN multilevel modeling software from within Stata. Journal of Statistical Software, forthcoming.

Linde, J. \& Ekman, J. (2003) Satisfaction with democracy: A note on a frequently used indicator in comparative politics. European Journal of Political Research, 42(3), pp. 391-408. 
Lipset, S. \& Rokkan, S. (1967) Party Systems and Voter Alignments: Cross-National Perspectives (New York: Free Press).

Lopez Pintor, R. \& Gratschew, M. (2002) Voter Turnout in Western Europe since 1945 (Stockholm: Int. IDEA).

Mainwaring, S. \& Zoco, E. (2007) Political sequences and the stabilization of interparty competition: Electoral volatility in old and new Democracies. Party Politics, 13(2), pp. 155-178.

Mair, P. (1993) Myths of electoral change and the survival of traditional parties. European Journal of Political Research, 24(1), pp. 121-133.

Mair, P. (2008) Electoral volatility and the Dutch party system: A comparative perspective. Acta Politica, 43(2/3), pp. 235-253.

Miller, A.H. \& Listhaug, O. (1990) Political parties and confidence in government: A comparison of Norway, Sweden and the United States. British Journal of Political Science, 20(3), pp. 357-386.

Neto, O. \& Cox, G. (1997) Electoral institutions, cleavage structures, and the number of parties. American Journal of Political Science, 41(1), pp. 149-174.

Nevitte, N., Blais, A., Gidengil, E. \& Nadeau, R. (2009) Socioeconomic status and nonvoting: A cross-national comparative analysis, in: H.-D. Klingemann (ed) The Comparative Study of Electoral Systems (New York: Oxford University Press), pp. 85-108.

Norris, P. (1999) Introduction: The growth of critical citizens?, in: P. Norris (ed) Critical Citizens: Global Support for Democratic Governance (Oxford: Oxford University Press), pp. 1-19.

Pedersen, M.N. (1979) The dynamics of European party systems: Changing patterns of electoral volatility. European Journal of Political Research, 7(1), pp. 1-26.

Powell, G.B.J. (1986) American Voter Turnout in Comparative Perspective. The American Political Science Review, 80(1), pp. 17-43.

Riker, W.H. \& Ordeshook, P.C. (1968) A Theory of the Calculus of Voting. The American Political Science Review, 62(1), pp. 25-42.

Söderlund, P. (2008) Retrospective voting and electoral volatility: A Nordic perspective. Scandinavian Political Studies, 31(2), pp. 217-240. 
Spiegelhalter, D.J., Best, N.G., Carlin, B.P. \& van der Linde, A. (2002) Bayesian measures of model complexity and fit. Journal of the Royal Statistical Society: Series B (Statistical Methodology), 64(4), pp. 583-639.

Steenbergen, M.R. \& Jones, B.S. (2002) Modeling multilevel data structures. American Journal of Political Science, 46(1), pp. 218-237.

Taagepera, R., Selb, P. \& Grofman, B. (2014) How turnout depends on the number of parties: A logical model. Journal of Elections, Public Opinion and Parties, 24(4), pp. 392-413.

Tavits, M. (2008) On the linkage between electoral volatility and party system instability in Central and Eastern Europe. European Journal of Political Research, 47(5), pp. 537-555.

The Comparative Study of Electoral Systems (www.cses.org). CSES MODULE 2 FULL RELEASE [dataset]. June 27, 2007.

The Comparative Study of Electoral Systems (www.cses.org). CSES MODULE 3 FULL RELEASE [dataset]. March 27, 2013 version.

Thomassen, J. (ed) (2014) Elections and Democracy. Representation and Accountability (Oxford: Oxford University Press).

Waldahl, R. \& Aardal, B. (2000) The accuracy of recalled previous voting: Evidence from Norwegian election study panels. Scandinavian Political Studies, 23(4), pp. 373-389.

Weber, T. (2011) Exit, voice, and cyclicality: A micrologic of midterm effects in European parliament elections. American Journal of Political Science, 55(4), pp. 907-922.

Whitten, G. \& Palmer, H.D. (1996). Heightening comparativists' concern for model choice: Voting behavior in Great Britain and the Netherlands. American Journal of Political Science, 40(1), pp. 231-260.

Zelle, C. (1995) Social dealignment versus political frustration: Contrasting explanations of the floating vote in Germany. European Journal of Political Research, 27(3), pp. 319-345. 
Table 1. Multinomial logit models explaining switching parties and switching to abstention

\begin{tabular}{|c|c|c|c|}
\hline & $\begin{array}{c}\text { Switched } \\
\text { parties versus } \\
\text { loyal } \\
\end{array}$ & $\begin{array}{l}\text { Abstained } \\
\text { versus loyal }\end{array}$ & $\begin{array}{c}\text { Abstained } \\
\text { versus switched } \\
\text { parties }\end{array}$ \\
\hline \multicolumn{4}{|l|}{ Individual level } \\
\hline Constant & $\begin{array}{l}1.911 * * * \\
(0.163)\end{array}$ & $\begin{array}{l}-0.390 \\
(0.316)\end{array}$ & $\begin{array}{c}-2.292 * * * \\
(0.363)\end{array}$ \\
\hline $\begin{array}{l}\text { Like-dislike of party } \\
\text { previously voted for }\end{array}$ & $\begin{array}{l}-4.672 * * * \\
(0.076)\end{array}$ & $\begin{array}{c}-3.359 * * * \\
(0.117)\end{array}$ & $\begin{array}{c}1.302 * * * \\
(0.123)\end{array}$ \\
\hline Satisfaction with democracy & $\begin{array}{l}-0.065 \\
(0.049)\end{array}$ & $\begin{array}{c}-0.652 * * * \\
(0.091)\end{array}$ & $\begin{array}{c}-0.584 * * * \\
(0.094)\end{array}$ \\
\hline Closeness to a party & $\begin{array}{c}-0.734 * * * \\
(0.029)\end{array}$ & $\begin{array}{c}-0.866 * * * \\
(0.053)\end{array}$ & $\begin{array}{l}-0.125^{*} \\
(0.057)\end{array}$ \\
\hline \multicolumn{4}{|l|}{ Contextual level } \\
\hline ENEP & $\begin{array}{c}0.200 * * * \\
(0.028)\end{array}$ & $\begin{array}{l}0.234 * * * \\
(0.059)\end{array}$ & $\begin{array}{c}0.009 \\
(0.066)\end{array}$ \\
\hline Compulsory voting & $\begin{array}{l}-0.366 \\
(0.273)\end{array}$ & $\begin{array}{c}-2.302 * * * \\
(0.707) \\
\end{array}$ & $\begin{array}{c}-1.536 * * * \\
(0.521) \\
\end{array}$ \\
\hline $\mathrm{N}$ observations & & 34,568 & \\
\hline N elections & & 36 & \\
\hline$\sigma_{\text {election-switching }}^{2}$ & & 0.293 & \\
\hline$\sigma_{\text {election-abstaining }}^{2}$ & & 1.323 & \\
\hline Bayesian DIC & & $43,918.48$ & \\
\hline
\end{tabular}

Entries are unstandardized coefficients of a multinomial multilevel logit model, estimated via runmlwin in Stata. MCMC estimation. Significance levels: $* \mathrm{p}<0.05 ; * * \mathrm{p}<0.01 ; * * * \mathrm{p}<0.001$. Variance components of the interceptonly model: $\sigma^{2}$ election-switching $=0.386 ; \sigma^{2}$ election-abstaining $=1.822$. 
Table 2. Multinomial logit models explaining switching parties and switching to abstention cross-level interaction

\begin{tabular}{|c|c|c|c|}
\hline & $\begin{array}{l}\text { Switched } \\
\text { parties } \\
\text { versus loyal }\end{array}$ & $\begin{array}{l}\text { Abstained } \\
\text { versus loyal }\end{array}$ & $\begin{array}{l}\text { Abstained } \\
\text { versus } \\
\text { switched } \\
\text { parties }\end{array}$ \\
\hline \multicolumn{4}{|l|}{ Individual level } \\
\hline Constant & $\begin{array}{c}0.656^{* * * *} \\
(0.149)\end{array}$ & $\begin{array}{l}-0.581 \\
(0.420)\end{array}$ & $\begin{array}{l}-2.024 * * * \\
(0.476)\end{array}$ \\
\hline $\begin{array}{l}\text { Like-dislike of party previously } \\
\text { voted for }\end{array}$ & $\begin{array}{l}-2.810 * * * \\
(0.283)\end{array}$ & $\begin{array}{c}-1.189 * * * \\
(0.364)\end{array}$ & $\begin{array}{c}1.324 * * * \\
(0.299)\end{array}$ \\
\hline Satisfaction with democracy & $\begin{array}{l}-0.058 \\
(0.051)\end{array}$ & $\begin{array}{c}-0.634 * * * \\
(0.091)\end{array}$ & $\begin{array}{c}-0.557 * * * \\
(0.094)\end{array}$ \\
\hline Closeness to a party & $\begin{array}{l}-0.705 * * * \\
(0.029)\end{array}$ & $\begin{array}{l}-0.846^{* * *} \\
(0.057)\end{array}$ & $\begin{array}{l}-0.134^{*} \\
(0.058)\end{array}$ \\
\hline \multicolumn{4}{|l|}{ Contextual level } \\
\hline ENEP & $\begin{array}{l}0.556 * * * \\
(0.029)\end{array}$ & $\begin{array}{l}0.301 * * * \\
(0.089)\end{array}$ & $\begin{array}{l}-0.132 * \\
(0.079)\end{array}$ \\
\hline Compulsory voting & $\begin{array}{l}-0.349 \\
(0.274)\end{array}$ & $\begin{array}{l}-2.648 * * * \\
(0.546)\end{array}$ & $\begin{array}{c}-1.611 * * \\
(0.711)\end{array}$ \\
\hline \multicolumn{4}{|l|}{ Cross-level interactions } \\
\hline $\begin{array}{l}\text { Like-dislike of party previously } \\
\text { voted for * ENEP }\end{array}$ & $\begin{array}{c}-0.508 * * * \\
(0.050) \\
\end{array}$ & $\begin{array}{c}-0.575^{* * *} * \\
(0.067) \\
\end{array}$ & $\begin{array}{c}0.043 \\
(0.058) \\
\end{array}$ \\
\hline N observations & & 34,568 & \\
\hline N elections & & 36 & \\
\hline$\sigma_{\text {constant election-switching }}^{2}$ & & 2.630 & \\
\hline$\sigma_{\text {constant election-abstaining }}^{2}$ & & 2.578 & \\
\hline$\sigma^{2}$ like-dislike election-switching & & 3.341 & \\
\hline$\sigma^{2}$ like-dislike election-abstaining & & 2.133 & \\
\hline Bayesian DIC & & $43,420.68$ & \\
\hline
\end{tabular}

Entries are unstandardized coefficients of a multinomial multilevel logit model, estimated via runmlwin in Stata. MCMC estimation. Significance levels: $* \mathrm{p}<0.05$; $* * \mathrm{p}<0.01 ; * * * \mathrm{p}<0.001$. Variance components of the interceptonly model: $\sigma^{2}$ election-switching $=0.386 ; \sigma^{2}$ election-abstaining $=1.822$. 
Figure 1. Probability of loyalty, switching and abstaining by liking the party previously voted for

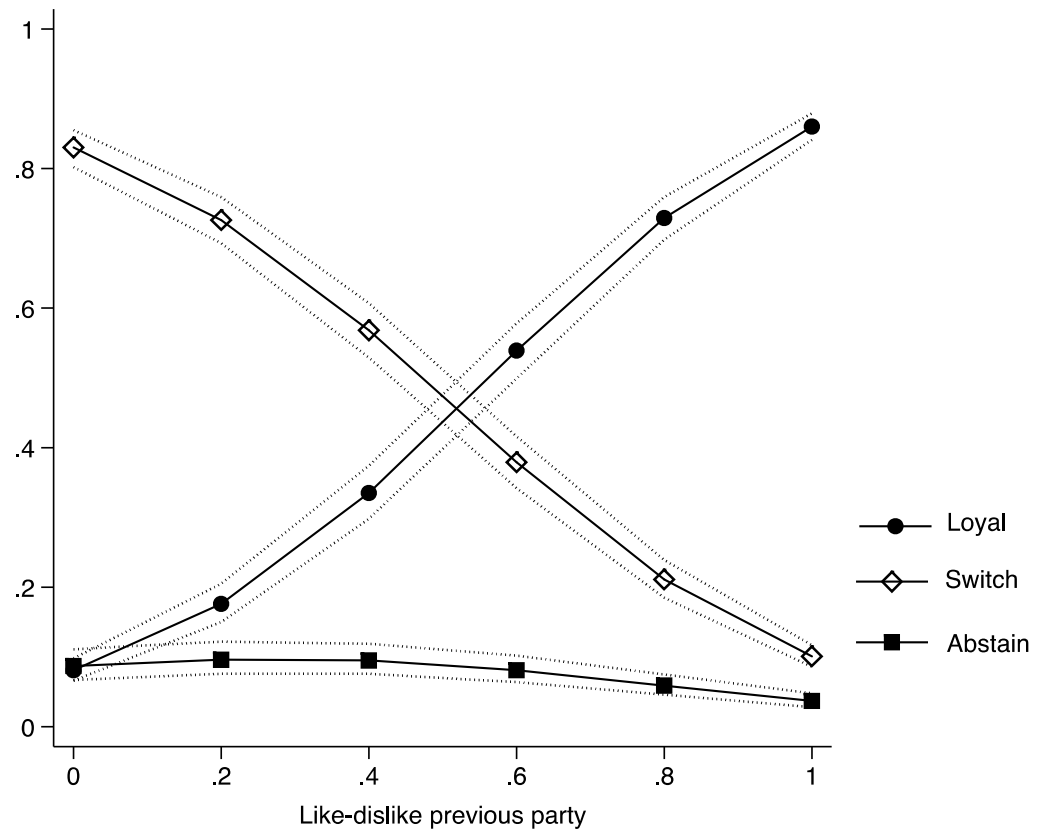

Predicted probabilities and 95\%-confidence intervals by like-dislike rating of previous party. Predictions with all covariates set at their sample means. Based on estimates of Model II in Table 2.

Figure 2. Probability of switching for different party system sizes

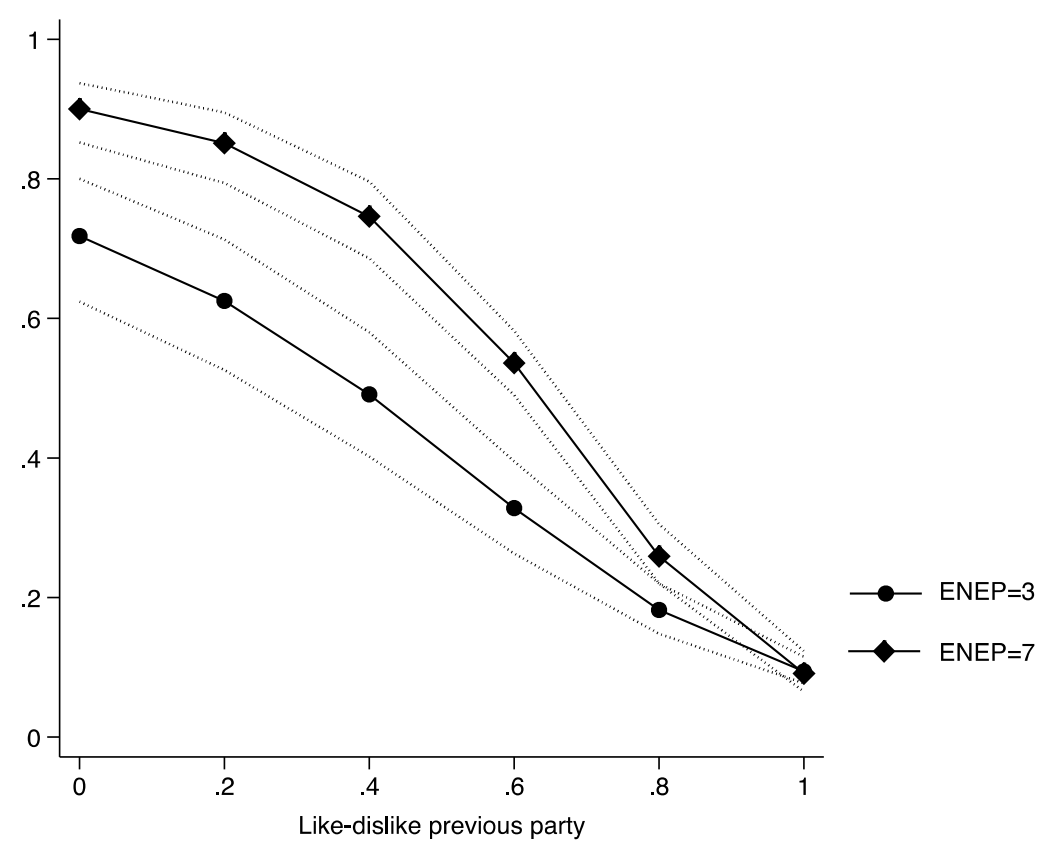

Predicted probabilities and 95\%-confidence intervals by like-dislike rating of previous party. Predictions with all covariates set at their sample means. Based on estimates in Table 3. 


\section{Endnotes}

i. Given that Belgium can be considered a country with two separate party systems, the Dutchand French-speaking samples for Belgium were considered different election-samples.

ii. A full overview of reasons for excluding some elections is provided in Appendix 2.

iii. Only election samples for which no single party's vote share was over 7.5 points off the official results and for which this bias strongly diverged from the bias in the survey year (over 5 points difference) were retained. Additional tests indicated that being stricter in which election samples to include for the analyses does not alter our conclusions. See Appendix 4 for detailed information on biases and Appendix 2 on which election samples were retained.

${ }^{i v}$. An extensive description of the coding of party switching for all countries included can be found in Appendix 3.

${ }^{v}$. Note that the addition of more control variables reduces the estimation sample at both the individual and the contextual level, see Appendix 5. 